УДК 612.171:616.124.2:577.112.386.2:616.127-005.02

\title{
Сократительная функция миокарда левого желудочка при нарушении метаболизма гомоцистеина у больных ишемической болезнью сердца
}

\author{
Никоненко А. С. ${ }^{1,2}$, Чмуль К. О. ${ }^{2}$, Никоненко А. А. ${ }^{2}$, Молодан А. В. ${ }^{1}$, Осауленко В. В. ${ }^{1}$ \\ ${ }^{1}$ ГУ «Запорожская медицинская академия последипломного образования МЗ Украины» \\ 2 Запорожский государственный медицинский университет
}

\begin{abstract}
Заболевания сердечно-сосудистой системы (ЗССС) - одна из самых острых медицинских и социальных проблем современного общества. В настоящее время установлено, что в прогрессировании ишемической болезни сердца (ИБС) и ее осложнений существенное значение имеет повышение уровня гомоцистеина. Однако в медицинских публикациях недостаточно освещены вопросы влияния гипергомоцистеинемии (ГГЦ) на течение атеросклероза и функциональное состояние миокарда, что требует более детального изучения этой проблемы.

Цель исследования - изучить функциональное состояние миокарда в зависимости от степени ГГЦ у больных ИБС, требующих хирургического вмешательства.

В исследовании был проведен анализ лабораторных данных 30 пациентов, страдающих атеросклерозом. Указанные изменения сократительной способности миокарда были более выражены у пациентов с гипергомоцистеинемией и мультифокальным атеросклерозом, что требует более тщательной медикаментозной коррекции после вмешательств на коронарных и сонных артериях.
\end{abstract}

Ключевые слова: ищемическая болезнь сердиа, гомоцистеин, гипергомоцистеинемия, эхокардиография, спеклтрекинг-эхокардиография, фракция выброса левого желудоча, стрейн, стрейн рейт, твист.

В последние годы увеличивается распространенность сердечно-сосудистых заболеваний, в первую очередь ишемической болезни сердца, смертность и инвалидность в результате которой постоянно растут. По показателям смертности от болезней системы кровообращения Украина занимает непрестижное первое место среди стран европейского сообщества. В настоящее время значительно вырос интерес исследователей к так называемым «нелипидным» факторам риска атеросклероза и ИБС [1, 2].

По современным представлениям, дисфункция эндотелия является ведущим патогенетическим звеном при гипергомоцистеинемии. Показано, что уровень гомоцистеина является независимым предиктором развития ИБС и связан с прогрессированием атеросклеротического процесса коронарных артерий, окклюзией венозных шунтов после реваскуляризации миокарда, рестенозом после ангиопластики и стентирования коронарных артерий, а также прогностическим маркером высокого риска смертности больных после коронарного шунтирования [3].

Возможность предсказания риска развития рестеноза у пациентов остается сложной и актуальной задачей. По данным некоторых зарубежных исследований, частота рестенозов коронарных артерий после хи- рургических вмешательств у больных с повышенным уровнем гомоцистеина в крови значительно варьирует $[6,7]$.

Современные исследования показывают, что, рассматривая ГЦ как предиктор многих заболеваний, следует «нижней» границы нормы считать более низкие показатели. Centers for Disease Control and Prevention (США) рекомендует для женщин моложе 60 лет значение 4,5-8,1 мкмоль/л, для мужчин - 6,3-11,2 мкмоль/л $[4,5]$.

Исследования последних лет подтверждают данные предположения и требуют более детального изучения этой проблемы. Однако в медицинских публикациях недостаточно освещены вопросы изучения влияния ГГЦ на функциональное состояние миокарда с помощью нового метода исследования состояния сердца спекл-трекинг-эхокардиографии (спекл-трекингЭхоКГ), особенно в оценке функции левого желудочка, а также выявления деформационных нарушений миокарда у больных с легкой степенью ГГЦ.

Спекл-трекинг-ЭхоКГ (speckle - пятно, метка, tracking - отслеживание) - современная эффективная методика оценки глобальной и локальной кинетики и деформации миокарда. Принцип технологии спеклтрекинг-ЭхоКГ заключается в том, что двухмерное 
изображение разделяется на маленькие сегменты (как мозаика). Комбинация пикселей серой шкалы каждого из сегментов уникальна, что позволяет отслеживать перемещение выбранных участков структур миокарда на протяжении сердечного цикла. Система анализирует любые точки и сегменты миокарда, выбранные оператором (на уровне эндокарда, миокарда, эпикарда). Полученные данные после обработки программным обеспечением представляются графически: кривые, цветная шкала, таблицы и векторы $[8,9]$.

Для анализа изображения спекл-трекинг-ЭхоКГ используют параметры, которые можно условно разделить на две группы: показатели движения и деформации. Эти, на первый взгляд, подобные процессы имеют принципиальные отличия [10]. Если объект двигается без изменения своей формы, это называется смещением. Если же отдельные части объекта двигаются с разной скоростью, то он меняет свою форму. Такой вид движения называют деформацией (стрейном). Производными от этих показателей является скорость смещения и деформации (стрейн рейт).

Общеизвестным фактом является то, что в 50-60\% случаев клинические проявления СН обусловлены снижением систолической функции левого желудочка (ЛЖ) с уменьшением фракции выброса (ФВ), увеличением конечно-диастолического объема (КДО), конечно-систолического объема (КСО) ЛЖ. Расчет таких показателей является обязательным для пациентов с сердечно-сосудистыми заболеваниями [11]. Однако на сегодняшний день доказано, что ФВ ЛЖ не является показателем сократимости ЛЖ.

Определение ФВ ЛЖ по L. Teichholz или M. A. Quinones с применением линейных размеров может давать неточные результаты, особенно у пациентов с региональной (локальной) дисфункцией ЛЖ. Это также касается другого метода оценки систолической функции ЛЖ - фракционного укорочения [12]. Методом выбора для оценки этих показателей в повседневной клинической практике в связи с широкой доступностью является 2D-эхокардиография (ЭхоКГ).

В XXI веке наиболее признанной моделью является концепция спиральной организации миокарда. Согласно последней, миокард составляет единство двух спиралевидных слоев волокон, где внутренний (субэндокардиальный) слой продольных волокон формирует закрученную правостороннюю спираль, а внешний (субэпикардиальный) слой - закрученную левостороннюю спираль. Внешние пучки волокон по мере углубления в сердечную стенку постепенно изменяют угол наклона, и на уровне середины стенки их ход становится циркулярным с углом наклона $0^{\circ}$. Внутренние пучки волокон идут в виде спирали обратного хода по отношению к внешним $[13,14]$.
Цель работы - изучить функциональное состояние миокарда в зависимости от степени гипергомоцистеинемии у больных ИБС.

Материалы и методы. Работа выполнена на базе отделения сердечно-сосудистой хирургии КУ «ЗОКБ 3ОР». В исследование были включены результаты обследования пациентов, страдавших ИБС, после получения информированного согласия. Критериями включения в исследования были пациенты с ишемической болезнью сердца с подтвержденной патологией коронарных артерий.

В исследование не включались пациенты старше 75 лет, больные с онкологической патологией, клапанными пороками сердца, заболеваниями почек, ревматическими заболеваниями, пациенты с заболеваниями желудочно-кишечного тракта.

Проанализированы данные 30 пациентов. Лиц мужского пола было 28 , женского - 2 . Средний возраст пациентов составил $57,2 \pm 5,48$ года.

В группах не было значимых различий по полу, возрасту, осложнениям и сопутствующей патологии.

Определение функционального класса стабильной стенокардии напряжения осуществлялось по классификации Канадской ассоциации кардиологов. Диагноз нестабильной стенокардии (НС) устанавливался согласно критериям Нью-Йоркской ассоциации кардиологов. Классы НС определялись по Е. Braunwald (1994).

У 100\% больных была выявлена гипертоническая болезнь 3-й стадии.

Большинство пациентов имели избыточную массу

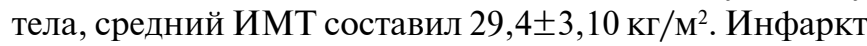
миокарда в анамнезе выявлен у 16 больных $(53,33 \%)$.

Согласно Канадской классификации (CCSA), пациентов с IV ФК стенокардии было 8 (26,6\%), III ФК стенокардии - 20 (66,6\%). Нестабильная стенокардия выявлена у $2(6,66 \%)$ пациентов, сердечная недостаточность 1 стадии - у $6(20,0 \%)$ пациентов, II стадия CH - была выявлена у $24(80,0 \%)$ больных.

Все больные были разделены на 3 группы в зависимости от уровня гомоцистеина. Первую группу составили 4 больных с нормальным уровнем ГЦ (до 10 мкмоль/л), с ишемической болезнью сердца, средний возраст составил 62 (57-69) года. Ко 2-й группе были отнесены 14 пациентов с легкой степенью ГГЦ (от 10-15 мкмоль/л), их средний возраст составил 56 (50-70) лет. В 3-ю группу включили 12 больных со средней степенью ГГЦ (от 15 до 30 мкмоль/л), средний возраст пациентов составил 57 (47-71) лет. Пациентов с тяжелой степенью ГГЦ не было.

В табл. 1 приведена характеристика обследованных пациентов.

Обследование пациентов предусматривало общеклинический этап (жалобы, анамнез, осмотр, паль- 


\section{Таблица 1}

Сравнительная характеристика пащиентов по группам

\begin{tabular}{|c|c|c|c|}
\hline Показатели & $\begin{array}{c}1 \text { группа } \\
(n=4)\end{array}$ & $\begin{array}{c}2 \text { группа } \\
(n=14)\end{array}$ & $\begin{array}{c}3 \text { группа } \\
(n=12)\end{array}$ \\
\hline $\begin{array}{l}\text { Гипертоническая } \\
\text { болезнь }\end{array}$ & $4(100 \%)$ & 14 (100\%) & $12(100 \%)$ \\
\hline $\begin{array}{l}\text { Постинфарктный } \\
\text { кардиосклероз }\end{array}$ & 2 (50\%) & $6(42,8 \%)$ & $8(66,7 \%)$ \\
\hline Сахарный диабет & 0 & $3(21,4 \%)$ & $3(25 \%)$ \\
\hline Средний ИМТ & $\begin{array}{c}27,7 \pm 2,60 \\
\mathrm{~K} \Gamma / \mathrm{M}^{2} \\
\end{array}$ & $\begin{array}{c}30,4 \pm 3,10 \\
\mathrm{~K} \Gamma / \mathrm{M}^{2}\end{array}$ & $\begin{array}{c}28,8 \pm 2,92 \\
\mathrm{~K} \Gamma / \mathrm{M}^{2}\end{array}$ \\
\hline Стенокардия, класс IV & 0 & $3(21,4 \%)$ & $3(25 \%)$ \\
\hline Стенокардия, класс III & $4(100 \%)$ & $11(78,5 \%)$ & $7(58,3 \%)$ \\
\hline $\begin{array}{l}\text { Нестабильная стено- } \\
\text { кардия }\end{array}$ & 0 & 0 & $2(16,6 \%)$ \\
\hline $\begin{array}{l}\text { Сердечная недоста- } \\
\text { точность, I класс }\end{array}$ & $1(25 \%)$ & 0 & 0 \\
\hline $\begin{array}{l}\text { Сердечная недоста- } \\
\text { точность, II класс }\end{array}$ & $3(75 \%)$ & 14 (100\%) & $12(100 \%)$ \\
\hline $\begin{array}{l}\text { Поражение сонных } \\
\text { артерий }\end{array}$ & 0 & 3 (21.4\%) & 12 (100\%) \\
\hline $\begin{array}{l}\text { Поражение артерий } \\
\text { нижних конечностей }\end{array}$ & 0 & $3(21,4 \%)$ & $6(50 \%)$ \\
\hline $\begin{array}{l}\text { ФВ ЛЖ } \\
\text { (методом ЭхоКС) }\end{array}$ & $58 \pm 2,0 \%$ & $58,2 \pm 2,0 \%$ & $49 \pm 1,0 \%$ \\
\hline
\end{tabular}

пация, перкуссия, аускультация), лабораторные исследования (ОАК, глюкоза, креатинин, мочевина крови), инструментальные обследования (рентгенография органов грудной клетки, фиброгастродуоденоскопия, ультразвуковое исследование органов брюшной полости).

Уровень гомоцистеина и витамина Д в плазме исследовался с помощью иммуноферментного анализатора «Sun rise TS», иммунофлюоресцентного анализатора «AiA 2000ST» (производитель «Tosoh Bioscience», Япония), электрохемилюминисцентного анализатора «Cobas e 411» (производитель «Roche Diagnostics», Германия).

Коронароангиографическое исследование проводилось на ангиографической установке Toshiba Medical Systems Corporation, INFX-8000V Snfinix VF-i/SP, также использовали диагностический томограф «TSX-101 A» Toshiba (Япония).

Спекл-трекинг-эхокардиография проводилась на ультразвуковом диагностическом аппарате Acuson X 700 «Siemens» (Германия).

Большинство данных обрабатывалось непараметрическими методами с использованием пакета статистических программ «Excel», Statistica 6.0. Статистический анализ результатов исследования производили с помощью компьютерной программы статистической обработки данных: в виде средних значений $(\mathrm{M} \pm \mathrm{m})$, непараметрических в виде Ме (25-75\%). Для оцен- ки значимости различий количественных параметров между двумя независимыми выборками использовали критерий Манна-Уитни. Достоверность различий в группах была принята при уровне статистической значимости $\mathrm{p}<0,05$.

Результаты и обсуждение. По результатам селективной коронарографии, у 30 (100\%) пациентов было выявлено многососудистое поражение коронарных артерий - в бассейне как правой, так и левой коронарной артерии.

Во 2-й группе преобладали пациенты с трехсосудистым поражением КА $(86,6 \%)$. В 3-й группе преобладали пациенты с четырехсосудистым поражением коронарных артерий $(92,4 \%)$. В 3-й группе преобладали пациенты с мультифокальным атеросклерозом: у 12 больных (100\%), по результатам ангиографии ветвей дуги аорты и дуплексного сканирования артерий мозга и артерий н/к, были выявлены поражения брахиоцефальных артерий и артерий н/к. Наиболее часто отмечалось поражение ВСА, преимущественно с двух сторон, что составило 96,8\% (11 больных), а также ОБА с двух сторон $-42,8 \%$ (6 больных).

В 97,0\% случаев пациентам была выполнена прямая реваскуляризация миокарда, а одному $(3,0 \%)$ пациенту имплантирован стент в коронарную артерию с лекарственным покрытием (до этого у пациента было выполнено аортокоронарное шунтирование).

У пациентов с ИБС выявлено снижение сегментарной ФВ ЛЖ, отмеченное в ишемизированных (по данным коронарографии) сегментах и более выраженное у пациентов с распространенным поражением коронарных артерий (табл. 2). В базальных отделах (перегородочном и боковом) и среднем перегородочном сегменте средние величины этих показателей в группе больных с ИБС были достоверно ниже, чем в группе здоровых лиц $(\mathrm{p}<0,05)$.

У больных с ИБС было выявлено снижение показателей продольной и циркулярной деформации. Так, снижение глобальной продольной деформации по

\section{Таблица 2}

Средние величины показателей сегментарной фракции

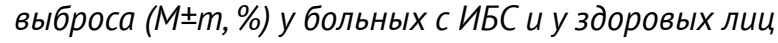

\begin{tabular}{lcc} 
Сегмент & Больные ИБС & Здоровые лица \\
\hline Базальный перегородочный & $52,9 \pm 6,3^{*}$ & $56,6 \pm 5,3$ \\
\hline Средний перегородочный & $40,4 \pm 5,5^{*}$ & $58,7 \pm 4,5$ \\
\hline $\begin{array}{l}\text { Апикальный } \\
\text { перегородочный }\end{array}$ & $42,8 \pm 6,2$ & $57,4 \pm 3,7$ \\
\hline Апикальный боковой & $49,4 \pm 5,3$ & $53,3 \pm 3,5$ \\
\hline Средний боковой & $51,1 \pm 4,7$ & $57,8 \pm 4,4$ \\
\hline Базальный боковой & $39,8 \pm 4,7^{*}$ & $54,4 \pm 3,5$
\end{tabular}

* - отличие от показателей здоровых достоверно $(\mathrm{p}<0,05)$ 


\section{Таблица 3}

Средние величины показателей продольной деформащии у больных ИБС и у здоровых лии

\begin{tabular}{|c|c|c|c|c|}
\hline \multirow[b]{2}{*}{ Сегмент } & \multicolumn{2}{|c|}{ Больные с ИБС } & \multicolumn{2}{|c|}{ Здоровые лица } \\
\hline & $\begin{array}{c}\text { Стрейн } \\
\text { (\%) }\end{array}$ & $\begin{array}{c}\text { Стрейн } \\
\text { рейт (1/c) }\end{array}$ & $\begin{array}{c}\text { Стрейн } \\
\text { (\%) }\end{array}$ & $\begin{array}{c}\text { Стрейн } \\
\text { рейт (1/c) }\end{array}$ \\
\hline $\begin{array}{l}\text { Продольный } \\
\text { стрейн ЛЖ }\end{array}$ & $-8,3 \pm 2,2^{*}$ & $0,75 \pm 0,50$ & $-16,8 \pm 3,8$ & $1,01 \pm 0,13$ \\
\hline $\begin{array}{l}\text { Циркулярный } \\
\text { базальный } \\
\text { стрейн ЛЖ }\end{array}$ & $-7,9 \pm 0,5^{*}$ & $0,56 \pm 0,03$ & $-17,7 \pm 1,1$ & $1,02 \pm 0,14$ \\
\hline $\begin{array}{l}\text { Циркулярный } \\
\text { апикальный } \\
\text { стрейн ЛЖ }\end{array}$ & $-14,2 \pm 1,2^{*}$ & $0,74 \pm 0,29$ & $-24,0 \pm 4,8$ & $1,0 \pm 0,14$ \\
\hline $\begin{array}{l}\text { Скручивание } \\
\text { ЛЖ (твист) }\end{array}$ & $-5,32 \pm 0,9^{*}$ & $0,32 \pm 0,1$ & $-9,9 \pm 1,2$ & $1,03 \pm 0,16$ \\
\hline
\end{tabular}

сравнению со здоровыми лицами составило 30\%. Достоверные различия отмечены при сравнении средних величин в базально-перегородочном сегменте (амплитуда, $\mathrm{p}<0,05)$ и в апикально-боковом сегменте (скорость, $\mathrm{p}<0,05$ ) (табл. 2). Средние величины всех основных показателей циркулярной деформации у больных с ИБС были достоверно ниже $(\mathrm{p}<0,05)$ (табл. 3). Наибольшие сдвиги отмечены у лиц с клинически более выраженным нарушением кровообращения - у пациентов с мультифокальным атеросклерозом и с ГГЦ.

Нами проведен анализ гемодинамики у больных ИБС методом ЭхоКС+ДГ в зависимости от уровня гомоцистеина.

\section{Таблица 5}

Средние величины показателей продольной деформации у больных ИБС со значениями гомоцистеина

до 15,0 мкмоль/л и дефицитом витамина Д и у здоровых лиц

Больные с ИБС Здоровые лица

$\begin{array}{ccccc}\text { Сегмент } & \begin{array}{c}\text { Стрейн } \\ (\%)\end{array} & \begin{array}{c}\text { Стрейн } \\ \text { рейт (1/c) }\end{array} & \begin{array}{c}\text { Стрейн } \\ (\%)\end{array} & \begin{array}{c}\text { Стрейн } \\ \text { рейт (1/c) }\end{array}\end{array}$

Продольный $\quad-8,4 \pm 1,1^{*} \quad 0,79 \pm 0,50 \quad-16,8 \pm 3,8 \quad 1,01 \pm 0,13$

стрейн ЛЖ

Циркулярный

базальный $\quad-9,3 \pm 0,5^{*} \quad 0,63 \pm 0,03 \quad-17,7 \pm 1,1 \quad 1,02 \pm 0,14$ стрейн ЛЖ

\section{Циркулярный}

апикальный $\quad-14,3 \pm 1,0 * \quad 0,71 \pm 0,29 \quad-24,0 \pm 4,8 \quad 1,0 \pm 0,14$

стрейн ЛЖ

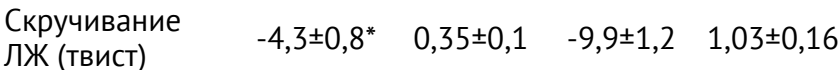

* - отличие от показателей здоровых достоверно $(\mathrm{p}<0,05)$

\section{Таблица 4}

Средние величины показателей продольной деформации у больных ИБС со значениями гомоцистеина до 10,0 мкмоль/л и дефицитом витамина Д и у здоровых лии

\begin{tabular}{lcccc} 
& \multicolumn{2}{c}{ Больные с ИБС } & \multicolumn{2}{c}{ Здоровые лица } \\
\cline { 2 - 5 } Сегмент & $\begin{array}{c}\text { Стрейн } \\
\text { (\%) }\end{array}$ & $\begin{array}{c}\text { Стрейн } \\
\text { рейт (1/с) }\end{array}$ & $\begin{array}{c}\text { Стрейн } \\
\text { (\%) }\end{array}$ & $\begin{array}{c}\text { Стрейн } \\
\text { рейт (1/с) }\end{array}$ \\
\hline $\begin{array}{l}\text { Продольный } \\
\text { стрейн ЛЖ }\end{array}$ & $-8,6 \pm 1,2^{*}$ & $0,81 \pm 0,50$ & $-16,8 \pm 3,8$ & $1,01 \pm 0,13$ \\
\hline $\begin{array}{l}\text { Циркулярный } \\
\text { базальный } \\
\text { стрейн ЛЖ }\end{array}$ & $-8,4 \pm 0,5^{*}$ & $0,57 \pm 0,03$ & $-17,7 \pm 1,1$ & $1,02 \pm 0,14$ \\
\hline $\begin{array}{l}\text { Циркулярный } \\
\text { апикальный } \\
\text { стрейн ЛЖ }\end{array}$ & $-15,3 \pm 1,2^{*}$ & $0,75 \pm 0,29$ & $\begin{array}{c}-24,0 \\
\pm 4,8\end{array}$ & $1,0 \pm 0,14$ \\
\hline $\begin{array}{l}\text { Скручивание } \\
\text { ЛЖ (твист) }\end{array}$ & $-7,2 \pm 0,9^{*}$ & $0,65 \pm 0,1$ & $-9,9 \pm 1,2$ & $1,03 \pm 0,16$ \\
& & & &
\end{tabular}

* - отличие от показателей здоровых достоверно $(\mathrm{p}<0,05)$

Практический интерес представляет проведенный анализ лабораторных данных пациентов и деформационных свойств их миокарда методом спеклтрекинг-ЭхоКГ и ЭхоКГ в зависимости от концентраций гомоцистеина плазмы крови, количества пораженных коронарных артерий и распространенности атеросклероза. По данным ЭхоКС, у пациентов 1-й и 2-й групп и группы здоровых лиц существенной разницы в гемодинамических показателях не выявлено, несмотря на разницу уровня ГЦ и распространенность атеросклероза. Имеются различия у пациентов 3-й группы - сниженная ФВ ЛЖ по сравнению с показателями 1-й и 2-й группы. Метод спекл-трекинг-

\section{Таблица 6}

Средние величины показателей продольной деформации у больных ИБС со значениями гомоцистеина до 30,0 мкмоль/л и дефицитом витамина Д и у здоровых лиц

\begin{tabular}{lcccc} 
& \multicolumn{2}{c}{ Больные с ИБС } & \multicolumn{2}{c}{ Здоровые лица } \\
\cline { 2 - 5 } Сегмент & $\begin{array}{c}\text { Стрейн } \\
\text { (\%) }\end{array}$ & $\begin{array}{c}\text { Стрейн } \\
\text { рейт (1/с) }\end{array}$ & $\begin{array}{c}\text { Стрейн } \\
\text { (\%) }\end{array}$ & $\begin{array}{c}\text { Стрейн } \\
\text { рейт (1/с) }\end{array}$ \\
\hline $\begin{array}{l}\text { Продольный } \\
\text { стрейн ЛЖ }\end{array}$ & $-7,9 \pm 1,0^{*}$ & $0,79 \pm 0,50$ & $-16,8 \pm 3,8$ & $1,01 \pm 0,13$ \\
\hline $\begin{array}{l}\text { Циркулярный } \\
\text { базальный } \\
\text { стрейн ЛЖ }\end{array}$ & $-6,2 \pm 0,6^{*}$ & $0,63 \pm 0,03$ & $-17,7 \pm 1,1$ & $1,02 \pm 0,14$ \\
\hline $\begin{array}{l}\text { Циркулярный } \\
\begin{array}{l}\text { апикальный } \\
\text { стрейн ЛЖ }\end{array}\end{array}$ & $-14,7 \pm 1,2^{*}$ & $0,71 \pm 0,29$ & $-24,0 \pm 4,8$ & $1,0 \pm 0,14$ \\
\hline $\begin{array}{l}\text { Скручивание } \\
\text { Лж (твист) }\end{array}$ & $-4,46 \pm 0,9^{*}$ & $0,35 \pm 0,1$ & $-9,9 \pm 1,2$ & $1,03 \pm 0,16$
\end{tabular}

* - отличие от показателей здоровых достоверно $(\mathrm{p}<0,05)$ 


\section{Таблица 7}

Показатели гемодинамики у больных ИБС со значениями гомоцистеина до 10,0 мкмоль/л

\begin{tabular}{lcc} 
Показатели & Больные ИБС & Здоровые \\
\hline КДР, мм & $58,46 \pm 1,26$ & $54,84 \pm 1,19$ \\
\hline КСР, мМ & $40,22 \pm 1,13$ & $35,4 \pm 1,33$ \\
\hline КДО, мл & $83,88 \pm 1,55$ & $81,7 \pm 1,42$ \\
\hline КСО, мл & $34,76 \pm 1,44$ & $31,9 \pm 1,21$ \\
\hline УО & $49,1 \pm 1,7$ & $52,7 \pm 1,18$ \\
\hline ФВ, \% & $58 \pm 2,0$ & $65 \pm 3,0$
\end{tabular}

ЭхоКГ, в отличие от обычных методов ЭхоКС, позволил установить, что пациенты 1-й и 2-й группы, а особенно 3-й группы с мультифокальным атеросклерозом и достоверно более высокими показателями гомоцистеина имели изменения функционального состояния миокарда - снижение глобальной продольной и циркулярной деформации.

В нашем исследовании выявлено, что у пациентов со средней степенью ГГЦ, в сравнении с представителями групп с легкой степенью и нормальным уровнем ГЦ, преобладали четырехсосудистые поражения коронарных артерий и поражение артерий мозга и артерий нижних конечностей. Также выявлено, что у пациентов с ГГЦ со средней степенью достоверно низкие показатели деформации миокарда левого желудочка по сравнению с группой контроля. Между этими группами больных достоверных различий в продольной и циркулярной деформации в базальном отделе и в области верхушки не выявлено. Достоверно была снижена только функция скручивания ЛЖ (твист) у пациентов с легкой степенью ГГЦ в сравнении с группой с нормальным уровнем ГГЦ.

У больных с мультифокальным атеросклеротическим поражением и высоким уровнем гомоцистеина при анализе деформационных свойств миокарда ЛЖ отмечено достоверное снижение продольной и циркулярной деформации ЛЖ в базальных отделах при сравнении с пациентами 1-й и 2-й групп. Снижение скручивания отмечено при сравнении с больными 1-й группы. Различий во 2-й и 3 -й группе по скручиванию ЛЖ не отмечено. Следовательно, чем больше распространенность атеросклероза и уровень ГЦ, тем более выраженными были изменения деформационных свойств миокарда ЛЖ. Отмечена зависимость степени снижения продольной, циркулярной деформации ЛЖ в базальных отделах и скручивания от количества пораженных KA.

Таким образом, нами было выявлено, что чем выше уровень гомоцистеина у пациентов ИБС, тем более выражена мультифокальность атеросклеротического поражения. У больных ИБС деформация миокарда

\section{Таблица 8}

Показатели гемодинамики у больных ИБС со значениями гомоцистеина до 15,0 мкмоль/л

\begin{tabular}{ll} 
Показатели & Больные ИБС \\
\hline КДР, мМ & $63,8 \pm 1,8$ \\
\hline КСР, мМ & $44,02 \pm 1,1$ \\
\hline КДО, мл & $133,2 \pm 1,5$ \\
\hline КСО, мл & $52,6 \pm 1,0$ \\
\hline УО & $74,2 \pm 1,3$ \\
\hline ФВ, \% & $58,2 \pm 2,0$
\end{tabular}

\section{Таблица 9}

Показатели гемодинамики у больных ИБС со значениями гомоцистеина до 30,0 мкмоль/л

\begin{tabular}{ll} 
Показатели & Больные ИБС \\
\hline КДР, мМ & $58,1 \pm 1,2$ \\
\hline КСР, Мм & $42,8 \pm 1,2$ \\
\hline КДО, мл & $104,8 \pm 1,2$ \\
\hline КСО, мл & $48,9 \pm 1,2$ \\
\hline УО & $55,9 \pm 1,2$ \\
\hline ФВ, \% & $49 \pm 1,0$
\end{tabular}

достоверно ниже, чем в группе контроля. Повышение уровня гомоцистеина до средних значений достоверно снижает функцию скручивания ЛЖ, существенно не изменяя продольную и циркулярные деформации базальных отделов и верхушки. При дальнейшем увеличении гомоцистеинемии до высоких цифр у пациентов с мультифокальным атеросклерозом происходит существенное снижение продольной и циркулярной дефомации в базальных отделах. Сегментарная деформация верхушки и скручивание ЛЖ достоверно не изменяются.

ГГЦ оказывает неблагоприятное воздействие на локальную сократительную функцию у пациентов ИБС, что следует учитывать перед проведением хирургических вмешательств.

\section{Выводы}

- Гипергомоцистеинемия является фактором риска развития ИБС и ассоциирована с неблагоприятным течением коронарной болезни.

- Нами выявлено, что чем выше уровень гомоцистеина, тем более выражено течение атеросклероза и изменения функционального состояния миокарда.

- Спекл-трекинг-ЭхоКГ позволяет регистрировать нарушения как глобального, так и регионального сократительного движения миокарда.

- Уменьшение показателей циркулярного стрейна, стрейн рейта и глобального продольного стрейна со снижением ротации в базальных отделах может 
служить важным маркером нарушения систолической функции при СН.

\section{Литература}

1. Некоторые генетические особенности метаболизма гомоцистеина, фолатов и монооксида азота как факторы риска ишемической болезни сердца / С. Г. Щербак [и др.] // Вестник Северо-Западного государственного медицинского университета им. И. И. Мечникова. - 2016. - Т. 8, № 1. - С. 123-130.

2. Наумов А. В. Три пути реметилирования гомоцистеина /А. В. Наумов, И. В. Данильчик, Ю. В. Сарана // Журнал Гродненского государственного медицинского университета. - 2016. - № 2 (54). - С. 27-32.

3. Наумов А. В. Гомоцистеин. Медико-биологические проблемы: монография / А. В. Наумов. - Минск : Профессиональные издания, 2013. - 311 с.

4. Механизмы развития эндотелиальной дисфункции и перспективы коррекции / С. Г. Дзугкоев, И. В. Можаева, Е. А. Такоева, Ф. С. Дзугкоева, О. И. Маргиева // Фундаментальные исследования. - 2014. - № 4. C. 198-204.

5. Хлыбова С. В. Влияние гомоцистеина на здоровье и репродукцию. Современный взгляд / Хлыбова С. В., Ипастова И. Д. // Status praesens. - 2015. - № 4. C. 101-108.

6. Фефелова Е. В. Механизм гиперкоагуляции при экспериментальной гипергомоцистеинемии / Е. В. Фефелова, Н. Н. Цыбиков, П. П. Терешков, А. В. Сепп, С. В. Изместьев // Тромбоз, гемостаз и реология. - 2015. - № 4 (64). - С. 27-30.

7. Фефелова Е. В. Морфологические изменения миокарда на фоне действия гомоцистеина / Е. В. Фефелова, С. В. Изместьев, А. В. Сепп, Н. Н. Цыбиков // Материалы Всероссийской научно-практической конференции с международным участием, посвященной 60-летию ЧГМА «Актуальные вопросы клинической и экспериментальной медицины» (Чита, 17-18 октября, 2013). - Чита : РИЦ ЧГМА, 2013. - Том 2. C. $189-190$.

8. Алехин М. Н. Ультразвуковые методики оценки деформации миокарда и их клиническое значение. Двухмерное отслеживание пятен серой шкалы ультразвукового изображения миокарда в оценке его деформации и скручивания / М. Н. Алехин // Ультразвуковая и функциональная диагностика. - 2011. № 3. - C. 107-112.

9. Segmental and global longitudinal strain rate based in echocardiography of 1266 healthy individuals: the HUNT study in Norway / H. Dalen, A. Thorstensen, S. Aase [et al.] // Eur. J. Echocardiogr. - 2010. - Vol. 11 (2). - P. 176-183.

10. Ткаченко С. Б., Берестень Н. Ф. Тканевое допплеровское исследование миокарда. - М. : Реал Тайм, 2016. - 176 с.

11. Рекомендации Европейского общества кардиологов (ESC) по диагностике и лечению острой и хронической сердечной недостаточности. 2012 // Новости медицины и фармации. - 2013. - № 447. - С. 26-41.

12. Optimizing ventricular fibers: uniform strain or stress, but not ATP consumption, leads to high efficiency / P. Nielsen, M. Vendelin, P. H. Bovendeerd [et al.] // Am. J. Physiol. Heart Circ. Physiol. - 2002. - № 283 (3). - P. 1072-1081.

13. Left ventricular structure and function: basic science for cardiac imaging / P. Sengupta, J. Korinek, M. Belohlavek [et al.] // J. Am. Coll. Cardiol. - 2016. - № 48 (10). P. 1988-2001.

14. Геометрія скорочення лівого шлуночка - новий погляд на проблему через призму структурної організації міокарда / В. М. Коваленко, О. Г. Несукай, О. О. Даниленко [та ін.] // Укр. мед. часопис. - 2013. - № 2. C. $183-187$.

\title{
The contractive function of the myocardium of the LV in the disturbance of homocysteine metabolism in IHD patients
}

\author{
Nikonenko A. S. ${ }^{1,2}$, Chmul K. O. ${ }^{2}$, Nikonenko A. A. ${ }^{2}$, Osaulenko V. V. ${ }^{1}$ \\ ${ }^{1}$ Zaporizhzhia Medical Academy of Postgraduate Education \\ ${ }^{2}$ Zaporizhzhia State Medical University
}

Diseases of the cardiovascular system (ZSSS) - one of the most acute medical and social problems of modern society. It has now been established that in the progression of IHD and its complications, an increase in the level of homocysteine is essential. However, medical publications do not adequately illustrate the study of the effect of HHC on the course of atherosclerosis and the functional state of the myocardium, which requires a more detailed study of this problem.

Purpose of the study: To study the functional state of the myocardium depending on the degree of hyperhomocysteinemia in patients with IHD requiring surgical measurement.

Materials and methods. The study analyzed the laboratory data of 30 patients suffering from atherosclerosis. Depending on the degree of GGZ, the patients were divided into 3 groups. These changes in myocardial contractility were more pronounced in patients with $\mathrm{HHC}$ and multifocal atherosclerosis, which requires a more thorough medical correction after surgery.

Results. Of practical interest is the analysis of patients and their deformation properties of the myocardium by the method of speckle tracking Echo-CG and Echo-KG, depending on the concentrations of GC of blood plasma, the number of coronary arteries and the prevalence of atherosclerosis. In our work comparing Echo-CS data, we found out that in patients of groups 1 and 2 and a group of healthy individuals, there was no significant difference in hemodynamic parameters, despite the difference in the GC level and prevalence of atherosclerosis. 
There are differences in patients in group 3, consisting of a reduced LVEF compared with the 1 st and 2 nd group. Using the method of speckle tracking Echo-CG, patients of the 1st group, that of the 2nd group, and especially of the 3rd group with multifocal atherosclerosis and significantly higher homocysteine parameters, had changes in the functional state of the myocardium-a decrease in global longitudinal and circular deformation, compared with the usual Echo-Ks methods.

Consequently, the greater the prevalence of atherosclerosis and the level of $\mathrm{HC}$, the more pronounced changes in deformation properties of the myocardium of the LV. Dependence of the degree of decrease in longitudinal, circular LV deformation in basal sections and twisting on the number of affected CA was noted.

Conclusions. Hyperhomocysteinemia is a risk factor for the development of coronary heart disease and is associated with an unfavorable course of coronary disease. We found that the higher the level of homocysteine, the more pronounced course of atherosclerosis and more pronounced changes in the functional state of the myocardium.

Key words: ischemic heart disease, homocysteine, hyperhomocysteinemia, echocardiography, speckle tracking echocardiography, left ventricular ejection fraction, strain, strain rate, twist.

\title{
Скорочувальна функція міокарда лівого шлуночка при порушенні метаболізму гомоцистеїну у хворих на ішемічну хворобу серця
}

\author{
Ніконенко О. С. ${ }^{1,2}$, Чмуль К. О. ${ }^{2}$, Ніконенко А. О. ${ }^{2}$, Молодан О. В. ${ }^{1}$, Осауленко В. В. ${ }^{1}$ \\ ${ }^{1}$ ДУ «Запорізька медична академія післядипломної освіти М03 України» \\ 2 Запорізький державний медичний уніиверситет
}

Захворювання серцево-судинної системи (ЗССС) - одна з найгостріших медичних і соціальних проблем сучасного суспільства. Наразі встановлено, що в прогресуванні ішемічної хвороби серця (IXC) та іï ускладнень істотне значення має підвищення рівня гомоцистеїну. Однак у медичних публікаціях недостатньо висвітлено питання впливу гіпергомоцистеїнемії (ГГЦ) на перебіг атеросклерозу і функціональний стан міокарда, що потребує більш детального вивчення цієї проблеми.

Мета дослідження - вивчити функціональний стан міокарда залежно від ступеня ГГЦ у хворих на IXC, які потребують хірургічного втручання.

Матеріали та методи. У дослідженні було проаналізовано лабораторні дані 30 пацієнтів, які страждають на атеросклероз. Залежно від ступеня ГГЦ пацієнтів розподілили на три групи. Зазначені зміни скорочувальної здатності міокарда були більш виражені у пацієнтів із ГГЦ і мультифокальним атеросклерозом, що потребує більш ретельної медикаментозної корекції після хірургічного втручання.

Результати. Практичний інтерес становить проведений аналіз лабораторних даних пацієнтів і деформаційних властивостей їх міокарда методом спекл-трекінг-ЕхоКГ і ЕхоКГ залежно від концентрацій ГЦ плазми крові, кількості уражених коронарних артерій і поширеності атеросклерозу. В нашій роботі порівняння даних ЕхоКС засвідчило, що в пацієнтів 1-ї та 2-ї групи та групи здорових осіб суттєвої різниці в гемодинамічних показниках не виявлено, незважаючи на різницю рівня ГЦ і поширеність атеросклерозу. $Є$ відмінності у пацієнтів 3-ї групи, які полягають у зниженій ФВ ЛШ порівняно з 1-ю та 2-ю групою. Методом спекл-трекінг-ЕхоКГ виявлено, пацієнти що 1-ї групи і 2-ї групи, а особливо 3-ї групи з мультифокальним атеросклерозом і достовірно вищими показниками гомоцистеїну мали зміни функціонального стану міокарда - зниження глобальної поздовжньої та циркулярної деформації порівняно зі звичайними методами ЕхоКс. Отже, чим більшою є поширеність атеросклерозу і рівень ГЦ, тим більш вираженими були зміни деформаційних властивостей міокарда ЛШ. Відзначено залежність ступеня зниження поздовжньої, циркулярної деформації ЛШ у базальних відділах і скручування від кількості уражених КА.

Висновки. Гіпергомоцистеїнемія є фактором ризику розвитку IXC і асоційована з несприятливим перебігом коронарної хвороби. Нами виявлено, що чим вищий рівень гомоцистеїну, тим більш виражений перебіг атеросклерозу і більш виражені зміни функціонального стану міокарда.

Ключові слова: ішемічна хвороба серия, гомоцистеїн, гіпергомоцистеїнемія, ехокардіографія, спекл-трекінгехокардіографія, фракція викиду лівого шлуночка, стрейн, стрейн рейт, твіст. 